\title{
The Study on Outsider disadvantage and Its Future Prospects
}

\author{
Jinxue Gong
}

\author{
East China University of Science and Technology School of Business, Shanghai City Xuhui \\ District, 200237
}

hunter2011@foxmail.com

Keywords: Outsiders disadvantage, Cause and effect, Study Review, Future Prospects.

\begin{abstract}
Foreign companies are always subject to local businesses more disadvantages and obstacles than the host country, many foreign scholars have expanded this research, but there are relatively little research in this area in our country. This paper summarizes the definitions, antecedents, consequences, elaborate research status of outsider disadvantage on the basis of terms previous literature, and for the lack of existing research, this paper conducted research for the future prospects.
\end{abstract}

\section{Introduction}

From the beginning of the 1960 s, scholars began to pay attention to the disadvantages of multinationals at overseas operations, with respect to the host of local enterprises generated. According to the transaction cost theory, Hymer considered the host enterprise market and environmental information for a better way to obtain, and therefore will not face a lot of trading risk, while foreign companies are contrary, so he first proposed the "exotic operating cost" The concept, which is defined as foreign companies must take in the course of business in the host country, and host of local companies are not required to bear the costs.

\section{The Definition of Outsiders Disadvantage}

Hymer thought that this difference cost comes from the environment by the cultural, political and economic differences caused by the need to coordinate geographical distance generated, and the cost of doing business in foreign countries face other factors. Kindleberger first of all held that foreign enterprises are facing cost disadvantage in international business practices. Zaheer proposes a new concept --liability of foreignness (LOF), that is able to produce cost competitive disadvantages multinationals at overseas investment, that is, with respect to the host country for local businesses when multinational corporations operating overseas encountered all additional costs. Exotic operating costs Zaheer proposed by outsiders weaknesses and Hymer presented has no significant substantive difference, since "outsiders disadvantages" concept has been widely accepted and applied research in the field of international business.

\section{The Reasons leading to Outsiders Disadvantage}

Zaheer considered outsiders disadvantages generated by the four, but four areas are not completely independent: (1) Costs associated with the geographical distance, such as the distance and across time zones and generate tourism, transport, the cost of coordination; (2) For the host country are not familiar with the environment, and the lack of local roots in host countries arising from firm-specific costs;(3) The host environment, such as the lack of legitimacy and economic nationalism in the host country; (4) Since the costs resulting from the home country environment, such as the US multinationals were not export restrictions on high technology to certain countries. The importance of these cost factors and methods will be varied to industries, companies, host country and the home country. In this paper, Zaheer proposed a disadvantage because outsiders, combining a summary of a number of scholars study the causes of outsiders disadvantage as follows: 
The distance between the host country and the home country. Eden and Miller considered the existence of distance forcing foreign companies to carry out business activities in the host country to bear additional costs between the home and host countries, where the "distance" refers not only to the geographical distance between the two countries, but also refers to two in terms of institutional, cultural and psychological distance between the countries.

Distance of system. Scott believes that the institutional environment pillar of the regulation, norms and cognitive pillar pillars. Kostova put forward the concept of institutional distance in order to more fully reflect countries or the difference between the degree of similarity in the regulation, norms and cognitive aspects of a national policy to explain the impact of social knowledge sharing and value system of the enterprise activity on the basis of the three-pillar theory of Scott on the system. Since the system (including regulations, norms and cognitive) differences, multinational companies need to take more cost of collecting and analyzing information on the host of local businesses. Kostova and Zaheer believe that the quality standards of countries is different, once they can not comply with such a system, they would have been discrimination in the host country. The host Government might also forced domestic political pressure to implement political discrimination for foreign companies.

Outsiders are not familiar with the host country environment. As outsiders, multinationals are not familiar with the host country's environment, from before entering the host country will have to spend a lot of manpower and resources to gather information on the host environment. In addition, foreign enterprises not only need to gather information related to the environment, but also learn to integrate this information be considered as a whole. Because of the current trend of economic integration, complexity and uncertainty of international competitive environment is gradually increased, which is exacerbated by the difficulty of understanding the host environment multinationals, but also increased the cost of collecting environmental information.

The cost of the environment caused by the host country. Host environment may also make enterprises due to lack of legitimacy or because of economic nationalism and suffered disadvantage. Legitimacy mechanism is the legal system refers to the concept of community, social norms, cultural attitudes, etc. that are recognized and became widely accepted notion, so Scott divided the legality into three categories, namely the legality of regulations, norms and legality of cognitive legitimacy.

Costs from the home country environment. Outsiders disadvantage is a binary and opposing views. In the binary point of view, outsiders may come from multinational disadvantage origin and destination of their investment. Thus, the home country and the host country's environment as will bring to the enterprise internationalization disadvantage. The home country of the multinational environment will generate discrimination and restrictions, some scholars believe that Chinese foreign direct investment by the mother country's economic and political influence, it will undermine the efficiency of enterprises in the host country and social relations. Home country taxation policies, currency exchange rates, economic openness and the overall level of development, etc. will also have a significant impact on business internationalization. For example, early in the pre-reform China limits foreign development of enterprises, enterprises are almost impossible to develop international business. The state will require enterprises to invest in overseas operations of strict examination and approval system, or for export enterprises and product specific technical restrictions, so that enterprises in the overseas market is difficult to use such resources and capabilities.

\section{Consequences of Outsiders Disadvantage}

The research For outsiders disadvantage outcomes focuses on two aspects of international business performance and corporate behavior of international companies:

International Entrepreneurial Performance. The researchers found that the greater disadvantage outsiders are, the poorer business performance will have. Barkema et al study found that the greater the cultural differences with the host country's foreign companies are more likely to fail. Luo and Peng found that cultural distance and foreign performance showed a significant 
negative correlation. Chinese scholars payns et al. conduct foreign companies survey in China and found the more weaknesses in the system from the outsiders, the higher the rate of foreign companies withdraw. Zaheer considered outsiders disadvantage is a dynamic concept, the performance aspects of the disadvantages will gradually become part of the host country with multinationals within disappear. Sethi and Judge also pointed out that with the host of enhanced economic liberalization trend, outsiders weaknesses will gradually weaken, multinational enterprise performance is gradually decreased.

Internationalization behavior. Foreign companies can rely on the "internal network" to deal with outsiders disadvantages, because companies can more easily obtain information from the network. Buckley study shows that the presence of outsiders disadvantage because companies will first invest in relatively close psychological distance as well as national history and culture associated with the increase in knowledge and learning opportunities will gradually invest in relatively far away from the Cultural Psychology country, because the state system and the psychological distance between close due have similar backgrounds, more friendliness, more conducive to business investment behavior overseas. Foreign companies entering the host country also tend to choose to hire local employees, both home and host countries cultural staff team allows employees to adapt to different cultural backgrounds disadvantage due to the more complex system, due to cultural psychological distance.

\section{Future Prospect}

For the research Status of outsider disadvantage, this paper argues that Chinese scholars may focus on the following:

To promote the development and improvement of outsiders disadvantage theory. Current outsiders disadvantage theory also expand the space, which made contributions to the theory of Chinese scholars.

To rich the research on outsider disadvantage mechanism. Chinese scholars can help to rich outsiders disadvantage mechanism from two aspects: Firstly, expand research perspective outsider disadvantage. An empirical study of outsiders disadvantages, put main focus on the strategic and resource perspectives on location selection, diversification strategy and resource acquisition. It means impact on entrepreneurial performance of outsiders disadvantage in international relations, but as an important and special resource, the impact of network is relative lack of international business study, therefore the research view needs to be broadened.

\section{References}

[1] Hymer, S. The international operations of national firms: A study of direct foreign investment. Cambridge: MIT Press. 1976: 34-35.

[2] Kindleberger, C. American business abroad. New Haven: University Press. 1969.

[3] Zaheer, S. Overcoming the liability of foreignness. The Academy of Management Journal. 1995, 38(2): 341-363.

[4] Eden, L., Miller, S. R. Distance matters: Liability of foreignness, institutional distance and ownership strategy. In: Hitt M. A. and Cheng J. Advances in international management. New York: Elsevier. 2004: 187-221.

[5] Scott, W.R. Institutions and organizations, Foundations For Organizational Science, Thousand Oaks, CA: Sage, 1995.

[6] Kostova, T. Success of the transnational transfer of organizational practices within multinational companies. Minnesota: University of Minnesota. 1996.

[7] Caves. International corporation: the industrial economics of foreign investment. Economica. 1971, 38(149). 
[8] Henisz, W., Williamson, O. Comparative economic organization within and between countries. Business and Politics. 1999, 1(3): 261-276.

[9] Lee, D.J. The effect of culture distance on the relational exchange between exporters importers: The case of Australian exporters. Journal of Global Marketing. 1998, (11). 